\title{
The Impact of Psychological Contracts Upon Trust and Commitment within Supplier-Buyer Relationships: A Social Exchange View
}

\author{
Russel P J Kingshott \\ Senior Lecturer, Massey University, Auckland, New Zealand
}

\author{
Dr Russel P J Kingshott \\ BCom (Hons), MCom (Curtin), PhD (UWA) \\ Department of Commerce, \\ Massey University \\ Private Bag 102904 \\ North Shore Mail Center \\ Auckland, New Zealand
}

Phone: +6494140800 extension 9474

Fax: $\quad+6494418177$

Email: r.kingshott@massey.ac.nz

\begin{abstract}
Central to this study is the emerging body of knowledge describing how social exchange relationships are being nurtured. By focusing upon social exchange theory it was shown that psychological contracts play an important role in helping build customer commitment. A random sample of 343 Australian distributor firms from within the motorized vehicle industry was used to test a model developed on the basis of social exchange theory. Psychological contracts are perceptual in nature and were found to encompass reciprocal obligations stemming directly from the relational orientation between suppliers and distributors. This construct was also shown to have a positive impact upon the level of trust and commitment within the relationship. These findings have significant managerial implications for the manner in which managerial decision makers are modelling the firm-customer relationship because trust and commitment are essential elements in the development and maintenance of such relationships. The theoretical and managerial implications discussed have highlighted the need for further studies because there are deficiencies in the marketing literature pertaining to this important construct.
\end{abstract}




\title{
The Impact of Psychological Contracts Upon Trust and Commitment within Supplier-Buyer Relationships: A Social Exchange View
}

\begin{abstract}
Central to this study is the emerging body of knowledge describing how social exchange relationships are being nurtured. By focusing upon social exchange theory it was shown that psychological contracts play an important role in helping build customer commitment. A random sample of 343 Australian distributor firms from within the motorized vehicle industry was used to test a model developed on the basis of social exchange theory. Psychological contracts are perceptual in nature and were found to encompass reciprocal obligations stemming directly from the relational orientation between suppliers and distributors. This construct was also shown to have a positive impact upon the level of trust and commitment within the relationship. These findings have significant managerial implications for the manner in which managerial decision makers are modelling the firm-customer relationship because trust and commitment are essential elements in the development and maintenance of such relationships. The theoretical and managerial implications discussed have highlighted the need for further studies because there are deficiencies in the marketing literature pertaining to this important construct.
\end{abstract}

\section{Introduction}

The proliferation of relational marketing studies explaining the changing role and increased significance of the discipline within the firm (Sheth and Parvatiyar 1995; Webster 1992) has resulted in social exchange theory (Homans 1961; Thibaut and Kelly 1959) becoming one of the dominant theoretical underpinnings in this increasingly important paradigm. Central to the theory is the growing presence of trust (cf. Anderson and Narus 1990; Doney and Cannon 1997; Dwyer, Schurr and Oh 1987), and, scholars have been able to show how firms that nurture trust are able to attract and secure customer commitment in both industrial (Morgan and Hunt 1994) and consumer (Garbarino and Johnson 1999) markets. Under social exchange, both trust and commitment are central tenants that result in high levels of dependence however these constructs cannot simply materialize but evolve as a result of some form of socialization process (Axelrod 1986; Doney and Cannon 1997; Ford 1980; Jones and George 1998; Williams 2001).

Growing levels of interdependence between firms and their business customers have been modelled from the perspective of the attraction, communication, expectation formation and norm development (Dwyer, Schurr and Oh 1987) between these parties. Despite the earlier seminal works by IMP group scholars tapping such dimensions (cf. Håkansson 1982; Ford 1978; Ford 1980) there still remains a paucity of related empirical studies explaining precisely how such relational facets are likely to impact upon those core constructs that can bring stability into the business-to-business relationship.

However, we do know that expectation and obligation formation are key determinants of relational continuity (Gordon, McKeage and Fox 1998; Heide and John 1990; Heide and Milner 1992; Joshi and Arnold 1998; Kauffman and Stern 1988; Noordeweir, John and Nevin 1990) and help contribute to the level of commitment devoted to the relationship. Commitment is comprised of both attitudinal and instrumental dimensions (Garbarino and Johnson 1999; Gundlach, Achrol and Mentzer 1995) thus firms are able to leverage such psychological bonds with customers (cf. Berry 1995; Gordon, McKeage and Fox 1998; Schuns and Schröeder 1996; Wilson 1990) through the anticipation of future returns in terms of expectations and obligations for remaining within the relationship. These have been modelled within the employment 
relationship from the perspective of the formation of psychological contracts (Herriot, Manning and Kidd 1997; Robinson, Kraatz and Rousseau 1994; Rousseau 1990). Whilst psychological contracts have been shown to exist within the context of internal customers (Llewellyn 2001) and business-to-business relationships (Kingshott 2002) this important stream of social exchange grounded literature has been largely unexplored within the marketing discipline.

In spite of such paucity, current employee relations literature depicts psychological contracts to comprise of an individual's belief that certain promises have been made by the other party (Robinson 1996; Robinson, Kraatz and Rousseau 1994; Rousseau 1990; 1995) and these act as strong psychological bonds between the parties (Anderson and Schalk 1998) because they reflect communications of future intent between them (Morrison and Wolfe 1997). Psychological contracts have been shown to be highly significant within this employment context because they help the employee frame the relationship and this serves to guide their behaviour. It should be noted that they are distinguishable from the normative contract (Rousseau 1995) because they reside in the mind of the individual, and can therefore act as double-edged swords because they also offer the potential to engender dispute and disagreement between parties (Rousseau and Parks 1993). By showing the positive and negative implications of psychological contracts this rapidly growing body of knowledge has been an important aspect in helping managers to understand the employment relationship. The earlier works of marketing scholars modelling distributor-supplier relationships from the perspective of social exchange (Anderson and Narus 1984, 1990; Ford 1980; Håkansson 1982) tends to suggest that the psychological contract is also likely to have both theoretical and managerial implications for marketing relationships grounded in social exchange theory.

Hence, it is posited those expectations and obligations that drive future action within the marketing relationship (cf. Bitner 1995; Boyle, Dwyer, Robicheaux, and Simpson 1992; Dwyer, Schurr and Oh 1987; Grönroos 1990; Weiner and Doescher 1992) can also be modelled under the auspices of the psychological contract, and, these will have an influence upon the level of trust and commitment. With this in mind, the main purpose of this research was to examine for the presence of this construct and then determine the bonding impact it will have upon these critical relational building constructs. In doing so it is anticipated that findings from the study will help managers understand some more factors they need to take into account when attempting to build and nurture longer-term firm-customers relationships from the perspective of social exchange.

\section{Theory and Hypothesis}

One of the key challenges facing firms is the need to model the firm-customer interface that can protect idiosyncratic investments at the same time as being able to maximize benefits from association (Brown, Dev and Lee 2000; Cannon, Achrol, and Gundlach 2000; Morgan and Hunt 1994). In this respect, the proliferation in relationship marketing literature has seen the emergence of the transactional cost analysis (TCA) perspective (cf. Noordewier, John and Nevin 1990; Weitz and Jap 1995; Williamson 1975, 1979) and social exchange theory (cf. Anderson and Narus 1984, 1990; Carman 1980; Doney and Cannon 1997; Dwyer, Schurr and Oh 1987; Homans 1961; Morgan and Hunt 1994; Thibaut and Kelly 1959) becoming the dominant theoretical perspectives in explaining how firms are responding to this challenge. Both approaches attempt to explain how managerial decision makers can deal with building and nurturing long-term marketing relationships but differ largely in relation to the mechanisms used to bring stability needed to maintain ongoing commitment from customer firms.

In fear of over simplification, the TCA relationship diverges from those based upon social exchange because of limited capacity of this approach in helping to explain the presence and influence of trust. By grounding marketing relationships in social exchange theory scholars are thus able to show the significance of trust between manufacturers and distributors (Anderson 
and Narus 1990), as well as how trusting behaviors can attract commitment in these and other firm-customer relational contexts (Garbarino and Johnson 1999; Morgan and Hunt 1994; Rexha, Kingshott and Aw 2003). Notably, successful marketing relationships are those that can attract commitment that is more than mere behavioral intent (Gundlach, Achrol and Mentzer 1995) and this is possible because the reliance inherent within trust (Moorman, Deshpandé, and Zaltman 1992; Swan and Nolan 1985) is capable of 'leveraging' such idiosyncratic and non-retrievable relational investments. Such instrumental commitment will result because of the capacity of trust to encompass high levels of consistency, stability and control within the relationship (Ganesan 1994), and, because commitment constitutes a critical determinant of relational continuity (Dwyer, Schurr and Oh 1987) it is so highly valued that exchange partners are always seeking "to develop and maintain this precious attribute in their relationships" (Morgan and Hunt 1994, p.23). Furthermore, trust also signifies the transformation from an unpredictable and indeterminate relationship to one that comprises relational stability because the presence of this construct is largely a function of being able to forecast the motives and behaviors of another (Doney and Cannon 1997).

The trust construct is highly temporal in nature and constitutes a central aspect of the social exchange relationship because it increases willingness to accept vulnerability (Deutch 1962). By mitigating the hazards of opportunism in this manner (Ganesan 1994) trust provides confidence in the partner's ability to perform as expected (Moorman, Zaltman and Deshpandé 1992; Morgan and Hunt 1994) and in doing so reflects the actions of the trustee through influence acceptance, communication openness, risk forbearance and control reduction (Smith and Barclay 1997). Whilst trust is inherent within social exchange relationships, the construct cannot simply materialize but evolves through some form of socialization process (Axelrod 1986; Jones and George 1998; Williams 2001) that embodies high levels of interaction between parties. The growing presence of trust in this manner indicates an orientation of parties upon ultimate values rather than immediate rewards of association (Huston and Burgess 1979). By increasing dependence upon one another in this manner, this demarks TCA from the social exchange relationship.

Within business-to-business relationships, Dwyer, Schurr and Oh (1987) describe how the various facets of interaction can result in the increase in the level of such interdependence between parties, and, this manifests largely through the extent of their attraction, communication, expectation formation and norm development. Placing impetus upon relational inputs in this manner also enables decision makers to take advantage of the norm of reciprocity and its capability to maintain solidarity, stability and commitment between relational parties by way of engendering mutual and enduring moral obligations (cf. Blau 1964; Ekeh 1974; Gouldner 1960).

Socialization involves learning about and adapting to the needs of either party to cater to the relationship requirements and thus such acquiescence represents critical signals of honorable intentions towards the relationship (Anderson and Weitz 1992; Gundlach, Achrol and Mentzer 1995). As these are incremental and concurrent they differ in intent from the TCA perspective as the latter type of relationship also involves input costs that are incurred well in advance of future exchange (Williamson 1983). This is likely to influence the governance choice from the onset of the relationship (Cannon, Achrol, and Gundlach 2000), and, as parties need to encompass measures that help protect these investments due to the fear of opportunism it has the net effect of making the TCA relationship relatively less flexible and inefficient (Rindfleisch and Heide 1997). However, under social exchange, socialization helps establish the best utility of the relationship resources (Hallén, Johanson and Seyed-Mohamed 1990) increasing exchange efficiencies (Brown, Chekitan and Lee 2000) and thus makes these types of relationships extremely attractive propositions for decision makers.

Hence, working closely together in this manner not only provides both parties with economic benefits of this nature but joint incremental adaptations stemming directly from their 
interaction largely overcomes the problem of opportunistic tendencies due to disproportionate instrumental inputs (Gundlach, Achrol and Mentzer 1995). This occurs principally because socialization not only influences the making of such idiosyncratic investments but the 'joint incremental' nature of the process ensures that they are mutual and proportional. These inputs are deeply embedded in relationship formation and maintenance and result in future expectations of rewards in return for their efforts (Heide and Milner 1992). Whilst they are occurring continuously in the relationships, they are prominent during early stages of interaction where the communication and bargaining between parties causes them to "rearrange their mutual distributions of obligations, benefits and burdens" (Dwyer, Schurr and Oh 1987, p.16). These authors model the effects of such obligations upon the growing levels of interdependence between buyer and supplier firms, and conceptualize them to contribute to growing levels of trust and commitment between these firms and help frame the overall relationship.

Such relational obligations have also been modeled within the employee-employer context but in the form of psychological contracts (cf. De-Meuse, Bergmann and Lester 2000; Guzzo and Noonan 1994; Herriot, Manning and Kidd 1997; Kickul 2001; Rousseau 1990; 1995). These contracts represent the belief that certain promises of future relational returns have been made (Robinson and Rousseau 1994) and can greatly influence the actions of the employee. Psychological contracts are also grounded in social exchange theory and have relational properties that bind the parties (Guzzo and Noonan 1994; Robinson, Kraatz, and Rousseau 1994) through the strong perceptions of mutual obligations. It is therefore posited that a central feature of building firm-customer interdependence will result in the formation of psychological contracts because this particular construct represents beliefs that commitments have been made, and, these have the effect of binding parties to some future action (Rousseau 1995). These have been shown to stem from both implicit and/or explicit promises of future exchange (Robinson, Kraatz, and Rousseau 1994) as a direct consequence of the interaction between employees and the employer (Guest 1998; Robinson 1996; Rousseau 1995) therefore also anticipated to result in marketing relationships built upon social exchange.

However, what distinguishes the psychological contract from other forms of agreement is that they are highly perceptual and idiosyncratic in nature (Anderson and Schalk 1998; Morrison and Robinson 1997; Rousseau 1990; 1995) and represent the employee's perception about their own, as well as their employer's relational obligations (Rousseau and Tijoriwali 1998). Hence, the perceived obligations that will act as the glue that binds parties (Guzzo and Noonan 1994) will also increase the level of reliance upon the other party and contribute to the building of trust and commitment within the firm-customer relationship. It is therefore posited that a firms' relational orientation will result in the building of trust and psychological contract and these two constructs will interact to strengthen the commitment within the relationships, reflected through the conceptual model below, and, expressed more formally in the following hypotheses:

H1: Relational orientation and relational trust are positively related.

H2: Relational orientation and psychological contracts are positively related.

H3: Psychological contracts and relational trust are positively related.

H4: Psychological contracts and relational commitment are positively related.

H5: Relational trust and relational commitment are positively related. 


\section{Figure 1}

\section{Effects of supplier relational orientation within the relationship}

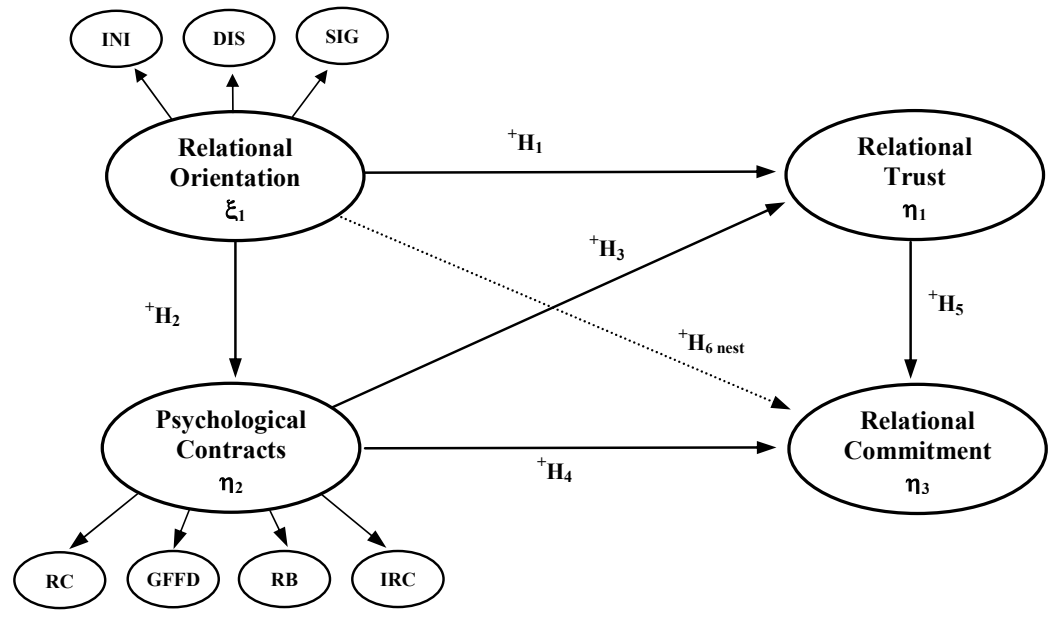

\section{Sample Frame}

\section{Method}

A national sample of 1,900 Australian distributor firms within the motorized vehicle industries was generated from a commercial database. Typical products distributed by the firms surveyed included motor vehicle supplies and parts, accessories, tools, and equipment, motorcycles and parts, motorboats and marine supplies, and, outboard motors and parts. Given the technical and complex nature of these offerings this meant that a highly interactive relationship between supplier and distributor firms was needed within the value chain. Furthermore, as these offerings represented key 'inputs' for the distributor's down-stream marketing activity it emphasized the critical importance of working closely with the supplier firm. Also, as many aspects of the product, such as technical support and servicing, were provided by the distributor on the manufacturer's behalf this ensured mutual relational inputs. Prior to the major fieldwork, 20 local businesses were identified from this industry and the research instrument was pre-tested to evaluate the respondents' interpretability of items.

\section{Procedure}

The Dillman (2000) method was used and this process took approximately ten weeks to complete. Respondents were contacted on four separate occasions with each mailing being personally addressed to the spare parts or service managers within selected distributor firms. The initial contact comprised a letter informing them of, and inviting them to participate in an important research project related to their industry as this improves response rates (Dillman 1991; Kanuk and Berenson 1975). This was immediately followed by the first of two 'datacollecting' mail-outs. The second of these mailing was sent four weeks later to those not responding, and, encompassed both a follow-up letter and another copy of the research instrument. The fourth mailing thanked each respondent for their participation and provided a summary of the findings. Although primarily designed to help increase the response rate, the two data collection mailings facilitated the monitoring of late and early returns and although not reported indicates that non-response bias (Armstrong and Overton 1977) was not problematic 
within the dataset. The fieldwork generated a total of 343 usable responses and this represented an effective response rate of 23 percent.

\section{Measures}

The main purpose of this study was to determine the effects of a firm's relational orientation upon psychological contracts, trust and commitment hence all measures comprise existing scales. However, given the variety of research contexts of the original measures, slight modifications were made to the semantics of some items to cater specifically to this particular supplier-distributor context (see appendix A for items). Some items were also dropped in the preliminary analysis of the measures using exploratory factor analysis (EFA) used to help 'repurify' the scales and help determine the validity of each of the measures. Although each of the 9 scales have been previously used in a variety of contexts the recommended two-step procedure (Anderson and Gerbing 1988) was not employed due to the need to reassess the appropriateness of each of the items in these scales. However when coupled with EFA, the correlation matrix results (see table 1) indicate discriminant and convergent validity.

Relational orientation is largely described in the literature as comprising behavior that embodies inputs designed to enhance the relational outcomes in a joint and mutual fashion (cf. Crosby, Evans and Cowles 1990; Leuthesser and Kohli 1995; Noordewier, John and Nevin 1990). This study concurs with the Leuthesser and Kohli (1995) view that relational orientation represents behavior designed to help enhance the mutualness between parties in their quest to achieve interdependent and joint outcomes because this embodies the essence of social exchange theory. Their measure was also used because it tapped the critical elements of interaction (Duncan and Moriety 1998; Dwyer, Schurr and Oh 1987; Morgan and Hunt 1994) most likely to propagate socialization through disclosing, signaling and initiating behaviors. This construct was higher order in nature and the three-factor scale developed by Leuthesser and Kohli (1995) captured the distributor's belief about the extent of the supplier firms' relational orientation based upon the nature of their interaction within the relationship.

Psychological contracts have been largely conceptualized in the literature as the extent an individual believes obligations, stemming from perceived or real promises has been made (Rousseau 1989; Rousseau and Parks 1993). From this, the study conforms to the Rousseau and Tijoriwali (1998) definition that this construct represents "an individual's belief in mutual obligations between that person and another party" (p.679) because it aptly represents the mental model framing those promises, acceptance and reliance (Rousseau 1995) that is expected the distributor firm surveyed will have with their suppliers. Subsequently, the measure encompassed most of the items within the four-factor scale developed by Rousseau (1996) to tap the extent that employees believed certain intrinsic and/or extrinsic promises were made as a consequence of the interaction with the employer. Although her scale captured the dimensions of good faith and fair dealing, intrinsic job characteristics, working benefits, and working conditions inherent within the employment relationship, these were modeled into this research context as good faith and fair dealing (GFFD), intrinsic relational characteristics (IRC) relational benefits $(\mathrm{RB})$, and, relational conditions (RC) respectively.

Finally, both the trust and commitment constructs were measured using the scales specifically developed by Morgan and Hunt (1994) for close marketing relationships and these tapped the constructs in our context at the general level using seven items in both scales. The definition used in this research coincided with theirs, namely that trust is the "confidence in the exchange partner's reliability and integrity" and similarly that commitment is "an exchange partner believing that an ongoing relationship with another is so important as to warrant maximum efforts at maintaining it" (p.23). Both measures were specifically developed by these two authors to tap these aspects within business-to-business marketing contexts and show general applicability in the context of this research. 


\section{Measurement Model}

\section{Research Findings}

As indicated confirmatory factor analysis (CFA) was not used to sequentially analyze both the measurement and structural models however EFA was applied to the original measures to help any purification effort and assist in the assessment of discriminant validity. This was followed by the structural model, and in doing so effectively conforms to the recommended twostep procedure (Anderson and Gerbing 1988). Despite pre-testing for item relevance, it was felt that an initial purification round of EFA was also required for the psychological contract scales (see appendix B) prior to assessing the measurement model. The rationale was that this measure comprising four factors had never been used within a marketing context prior to this study. This procedure resulted in the 29 items encompassing the four psychological contract sub-measures (Rousseau 1996) being subject to an initial phase of EFA to assess the dimensionality of the construct and identify problematic items. From this a total of 5-items were eliminated from the relational benefit (3-items) and relational condition (2-items) measures. Despite the need for such purification, the results (see appendix B) show that the original four-factor structure was largely replicated indicating general robustness of this multi-faceted construct at the operational level. As the alpha-indices of each of these four measures (see table 1) range from 0.88 to 0.96 this also indicates high measure reliability.

By subjecting the 9 constructs encapsulated by the remaining 50 items to a second phase of EFA, the results (see appendix C) show evidence of discriminant validity between these measures. During this procedure the four-factor structure of the psychological contract construct also remained intact indicating further evidence of the robustness of these and the other construct measures. The summative data in table 1 below provides a general overview of the mean values, standard deviations, the inter-correlations between the twelve measures of the four constructs and their reliability coefficients. Given that the $\alpha$-coefficients range from 0.96 to 0.83 , this provides evidence of acceptable reliability standards for each of the multi-item construct measures.

Table 1: Data Summarization, Reliability Coefficients and Correlation Matrix

\begin{tabular}{|c|c|c|c|c|c|c|c|c|c|c|}
\hline \multirow{2}{*}{ Construct } & \multirow{2}{*}{ Mean $^{a}$} & \multicolumn{3}{|c|}{ Relational Orientation } & \multicolumn{4}{|c|}{ Psychological Contract } & \multirow{2}{*}{$\begin{array}{c}\text { Trust } \\
\text { TR }\end{array}$} & \multirow{2}{*}{$\frac{\text { Commit }}{\text { COM }}$} \\
\hline & & SIG & DIS & INI & $\mathrm{RC}$ & GFFD & $\mathrm{RB}$ & IRC & & \\
\hline SIG & 4.248 & $(2.532)^{\mathrm{b}}$ & & & & & & & & \\
\hline DIS & 5.557 & 0.169 & $(2.241)^{\mathrm{b}}$ & & & & & & & \\
\hline INI & 4.685 & 0.228 & 0.525 & $(2.379)^{\mathrm{b}}$ & & & & & & \\
\hline $\mathrm{RC}$ & 5.790 & 0.123 & 0.323 & 0.403 & $(2.135)^{\mathrm{b}}$ & & & & & \\
\hline GFFD & 6.287 & 0.206 & 0.369 & 0.417 & 0.401 & $(2.208)^{\mathrm{b}}$ & & & & \\
\hline $\mathrm{RB}$ & 4.464 & 0.094 & 0.333 & 0.398 & 0.472 & 0.371 & $(2.614)^{\mathrm{b}}$ & & & \\
\hline IRC & 5.785 & 0.117 & 0.317 & 0.363 & 0.450 & 0.515 & 0.472 & $(2.187)^{\mathrm{b}}$ & & \\
\hline TR & 5.774 & 0.153 & 0.418 & 0.442 & 0.295 & 0.498 & 0.284 & 0.388 & $(2.354)^{\mathrm{b}}$ & \\
\hline $\mathrm{COM}$ & 7.450 & 0.332 & 0.302 & 0.343 & 0.341 & 0.416 & 0.274 & 0.437 & 0.488 & $(1.801)^{\mathrm{b}}$ \\
\hline & & $(0.83)^{\mathrm{c}}$ & $(0.86)^{\mathrm{c}}$ & $(0.92)^{c}$ & $(0.88)^{\mathrm{c}}$ & $(0.96)^{\mathrm{c}}$ & $(0.90)^{\mathrm{c}}$ & $(0.87)^{\mathrm{c}}$ & $(0.94)^{\mathrm{c}}$ & $(0.87)^{c}$ \\
\hline
\end{tabular}

\section{Structural Model}

The stronger test of the hypothesized relationships stemming from the outlined theoretical model, in Figure 1, was conducted with the aid of AMOS 5 (Arbuckle 1994-2003). Results of the analysis are shown in Table 2 below. Consideration of the validity of this model was made in comparison with a nested model that comprised an additional path $\left(\mathrm{H}_{6 n}\right.$ est $)$ because of the view that firms adopting a relational mode are likely to be more committed to the relationship. However, based upon the overall model analysis the highly favorable fit statistics indicate a structurally sound $\left[\chi_{(23)}^{2}=145.482 ; p=0.000 ; \quad\right.$ GFI $=0.916 ; \quad$ RMSEA $=0.025 ; \quad$ NNFI $=0.882$; 
$\mathrm{NFI}=0.912$; $\mathrm{AGFI}=0.835$; and, $\mathrm{CFI}=0.924]$ theoretical model. Comparisons between these fit statistics and those pertaining to the nested model reveal no significant improvement in model fit $\quad\left[\chi_{(22)}^{2}=143.239 ; \quad p=0.000 ; \quad\right.$ GFI $=0.917 ; \quad$ RMSEA $=0.027 ; \quad$ NNFI $=0.878 ; \quad$ NFI $=0.974$; $\mathrm{AGFI}=0.831$; and, $\mathrm{CFI}=0.925]$ confirming the more robust nature of the proposed theoretical model. The robustness of this model is complimented further through the favourable direction of path weightings and significant $p$-values that offer strong support for all five of the original hypotheses.

In supporting hypothesis 1 and 2 , the data presented clearly shows that firms adopting a relational orientation strategy are able to build trust with the customer firm $\left(\gamma_{11}=+0.425\right.$; $p=0.000)$, and, the respective development of a very strong psychological contract directed $\left(\gamma_{21}=+0.768 ; p=0.000\right)$ towards those firms within the relationship also indicates expectations of reliance. Consequently, the presence of the distributor's psychological contract was also found to have a positive effect upon both relational trust $\left(\beta_{12}=+0.321 ; p=0.000\right)$ and commitment $\left(\beta_{32}=+0.412 ; p=0.000\right)$ therefore also supporting both hypothesis 3 and 4 respectively. The results of hypothesis $5\left(\beta_{31}=+0.312 ; p=0.035\right)$ offer additional support for the rapidly growing body of evidence depicting the trust-commitment nexus within the marketing literature. Finally, the lack of both statistical and directional support for the hypothesis $\left(\mathrm{H}_{6 \text { nest }}\right)$ that a firm's relational orientation will result in greater relational commitment $\left(\beta_{32}=-0.134 ; p=0.148\right)$, representing the nested model is somewhat surprising considering that the exogenous construct in the model is highly temporal.

Table 2: Construct Structural Model

\begin{tabular}{|c|c|c|c|c|c|c|c|c|}
\hline \multicolumn{2}{|l|}{ Linkages in Model } & Path & Dir & Para. & \multicolumn{2}{|c|}{$\begin{array}{c}\text { Theoretical } \\
\text { Estimate } p \text {-value }\end{array}$} & \multicolumn{2}{|c|}{$\begin{array}{c}\text { Nested } \\
\text { Estimate } p \text {-value }\end{array}$} \\
\hline \multicolumn{2}{|l|}{ Exogenous } & & & & & & & \\
\hline \multirow{3}{*}{\multicolumn{2}{|c|}{$\begin{array}{l}\text { Relational Orientation - Relational Trust } \\
\text { Relational Orientation - Psychological Contract } \\
\text { Relational Orientation - Commitment }\end{array}$}} & $\mathrm{H} 1$ & $+\mathrm{ve}$ & $\gamma_{11}$ & +0.425 & 0.000 & +0.455 & 0.000 \\
\hline & & $\mathrm{H} 2$ & $+\mathrm{ve}$ & $\gamma_{21}$ & +0.768 & 0.000 & +0.776 & 0.000 \\
\hline & & $\mathrm{H} 6_{\text {nest }}$ & $+\mathrm{ve}$ & $\gamma_{31}$ & - & - & -0.134 & 0.148 \\
\hline \multicolumn{9}{|l|}{ Endogenous } \\
\hline \multirow{3}{*}{\multicolumn{2}{|c|}{$\begin{array}{l}\text { Psychological Contracts - Relational Trust } \\
\text { Psychological Contracts - Commitment } \\
\text { Relational Trust - Commitment }\end{array}$}} & $\mathrm{H} 3$ & $+\mathrm{ve}$ & $\beta_{12}$ & +0.321 & 0.000 & +0.316 & 0.000 \\
\hline & & $\mathrm{H} 4$ & $+\mathrm{ve}$ & $\beta_{32}$ & +0.412 & 0.000 & +0.500 & 0.000 \\
\hline & & H5 & $+\mathrm{ve}$ & $\beta_{31}$ & +0.375 & 0.000 & +0.409 & 0.000 \\
\hline \multicolumn{9}{|l|}{ Model Diagnostics } \\
\hline \multicolumn{3}{|c|}{\begin{tabular}{lll}
\multicolumn{2}{l}{ Theoretical Model } \\
$\chi^{2}=145.482$ & GFI $=0.916$ & NFI $=0.912$ \\
$\mathrm{df}=23$ & RMSEA $=0.025$ & AGFI $=0.835$ \\
$\mathrm{p}=0.000$ & NNFI $=0.882$ & $\mathrm{CFI}=0.924$
\end{tabular}} & \multicolumn{2}{|c|}{$\begin{array}{l}\text { Nested Model } \\
\chi^{2}=143.239 \\
\mathrm{df}=22 \\
\mathrm{p}=0.000\end{array}$} & $\begin{array}{l}\text { GFI }=0 \\
\text { RMSE } f \\
\text { NNFI }=\end{array}$ & $\begin{array}{l}917 \\
=0.027 \\
0.878\end{array}$ & \multicolumn{2}{|c|}{$\begin{array}{l}\mathrm{NFI}=0.914 \\
\mathrm{AGFI}=0.831 \\
\mathrm{CFI}=0.925\end{array}$} \\
\hline
\end{tabular}

Notwithstanding the unfavorable result of the nested hypothesis $\left(\gamma_{31}=-0.134 ; p=0.148\right)$ the overall impact of the additional path in the model also shows no significant improvement from its inclusion. It therefore tends to provide further evidence of the robustness of the proposed theoretical model because the nested path shows the additional path $\left(\gamma_{31}\right)$ into the analysis to in fact have a slight negative impact upon the fit statistics. Commitment seemingly has been enhanced through the expectations of future obligations and outcomes by way of the psychological contract $\left(\beta_{32}=+0.412\right)$ and the expectations of reliance of performance through trust $\left(\beta_{31}=+0.409\right)$ as juxtaposed to the direct relational actions of the supplier firm. In effect this shows the over-riding capability of psychological and social bonding (cf. Berry 1995) within the 
supplier-distributor relationship and forms the basis of discussion and elaboration in the final two sections of this article.

\section{Theoretical Implications and Suggestions for Future Research}

As we have seen the findings from the study provide additional support for the increasing body of empirical literature within marketing relationships depicting the significance of social exchange theory in helping to describe the marketing relationship (cf. Anderson and Narus 1984, 1990; Cannon, Achrol and Gundlach 2000; Dwyer, Schurr and Oh 1987; Heide and John 1992; Joshi and Arnold 1998; Kaufmann and Stern 1988; Morgan and Hunt 1994). However, this study offers a further contribution to existing literature because it extends current knowledge within this domain and this provides direction through a number of perspectives. It is posited that there is urgent need for more empirical studies along these lines because it identifies a number of theoretical considerations that have seemingly been overlooked in relation to the increasingly important marketing paradigm. Whilst the findings form the basis of the discussion for the remainder of this section, it is not intended to represent an exhaustive account of the research trajectories that the study is likely to stimulate.

Firstly, it can be seen that firms wishing to adopt a relational orientation with the customer firm need to be aware that signals sent during interaction and socialization will result in future expectations and obligations within the relationship. Sending signals and communicating are essential elements within the marketing relationship (Duncan and Moriety 1998) but these are likely to result in anticipation of future actions that may not necessarily be clearly understood by both parties. This is critical given that communication was found to have a positive impact upon the level of trust between manufacturers and their distributor partner firms (Anderson and Narus 1990). However, whilst the findings in this research is largely consistent with the earlier conceptualizations of developing relationships (cf. Dwyer, Schurr and Oh 1987; Ford 1980; Håkansson 1982) it differs as this study shows that these expectations and obligations can be successfully modeled from the perspective of psychological contracts. Terms of the psychological contract seemingly can have positive bonding effects between the firm and the customer as evidenced through the three hypotheses forming the psychological contract-trustcommitment nexus $\left(\beta_{12}, \beta_{32}\right.$ and $\left.\beta_{31}\right)$. However, as the latter two constructs are regarded as key elements of successful close marketing relationships (cf. Dwyer, Schurr and Oh 1987; Ford 1980; Morgan and Hunt 1994; Wilson 1995) the likely positive and negative impact of the psychological contract needs further examination. We have seen evidence of the bonding effect in this study but the negative consequences in relation to non-performance, or breaches as they are known, also need to be examined within the marketing context.

The effects of such contracts breaches have been empirically explored within the employee relation literature (cf. Kickul 2001; Rousseau 1990; Turnley and Feldman 1999) and these findings suggest that there is also merit to investigate the consequences of contract failure in the business-to-business context. At the general level, the presence of the psychological contract acts as a double-edged sword because of the concurrent relational bonding effects and the capability of the construct to engender dispute and disagreement (Rousseau and Parks 1993). It should be noted that contract breaches are both real and perceptual in nature and these have the effect of stimulating a wide range of emotions that serve the purpose of provoking behavior. Under social exchange relationships breaches are akin to exchange episodes and as these have positive and negative relational consequences (Ford 1980; Håkansson 1982) the effect of breaches upon the relational building capabilities will also need to be explored further.

Perhaps marketing scholars can draw upon the existing body of knowledge that has extended the earlier work of Hirschman (1970) that offer an EVLN typology (Farrell 1983; Rusbult Farrell, Rogers and Mainous 1988; Turnley and Feldman 1999) to represent the potential range of employee responses stemming from non-performance of the psychological 
contract. These studies indicate that employee responses to non-performance to comprise both constructive and destructive actions, however this is contingent upon the extent of employee loyalty, as well as the attribution given to the perceived failure (cf. Guest 1998; Kickul 2001; Morrison and Robinson 1997; Robinson 1996; Rousseau 1989; Turnley and Feldman 1998; 1999). This avenue of investigation may prove to be fruitful because marketing relationships are temporal in nature and critical constructs such as trust and commitment may moderate loyalty and thus the impact of non-performance upon the relationship. Interestingly, and perhaps more specific to the overall well-being of the social exchanged based supplier-distributor relationship, is the finding that contract failures eroded trust in the employer (Robinson 1996) and given that trust is reliance based (cf. Doney and Cannon 1997; Swan and Nolan 1985) any breaches to the terms of the psychological contract are likely to impede the contract-trust-commitment link and have a negative impact within the relationship.

Within marketing the results from the only other study encapsulating the effects of breaches to the psychological contract have shown these to be negative (cf. Llewellyn 2001). However, it should be noted that this study pertained to the internal service relationship within a large telecommunications study, and, the research design was an inductive lead case study. Hence, further empirical studies are required to assess the range of outcomes because the effects of nonperformance are posited not always to be negative episodes within the marketing relationship given the ability of partner firms to provide and accept constructive approaches to problem solving to be one of the hallmarks of successful relationships (cf. Boyle, Dwyer, Robicheaux and Simpson 1992; Dion, Banting and Hasey 1990; Leuthesser 1997; Morgan and Hunt 1994; Sriram, Krapfel and Spekman 1992). From this vantage point, it is worth investigation the conditions that lead to non-performance to determine which of these are likely to lead to constructive/destructive behaviors, and in particular the precise effect upon critical relationship building constructs such as trust, norms and commitment.

Secondly, the employee relation literature suggests that psychological contracts have both transactional and relational elements (Herriot, Manning and Kidd 1997; Robinson, Kraatz and Rousseau 1994; Rousseau 1990; Rousseau and Parks 1993) and these two types of contract are also likely to have a variety of relational building effects. Based upon this body of knowledge, transactional elements represent short-term outcomes expected from the association and tend to be more quantifiable over a finite and brief time frame. Whereas, relational obligations also found represented perceptions of what was owed by the supplier firm were seemingly intangible and greatly helped maintain the longevity of this relationship due to the anticipation of a range of unspecified future benefits from the association. They are highly congruous with current conceptualizations related to discrete and relational aspects of the marketing relationship (cf. Dwyer, Schurr and Oh 1987; Joshi and Arnold 1998; Webster 1992) however it should be noted that the latter terms of the psychological contract begin to dominate the life-space of the relationship as it endures (Guzzo and Noonan 1994).

The changing nature and structure of expectations and obligations are not only likely to increase as the relationship endures but they help propagate a relationship that becomes more open-ended. This will result in relational expectations and obligations becoming more nebulous and idiosyncratic in nature and posited to have the net effect of increasing relational bonding between firms. Under social exchange the anticipation of valuable future outcomes is believed to enhance reciprocity (Heide and Milner 1992; Weiner and Doescher 1994) and this largely helps maintain solidarity, stability and commitment between relational parties by way of engendering mutual and enduring moral obligations (cf. Blau 1964; Ekeh 1974; Gouldner 1960). If these are encapsulated under the auspices of the psychological contract then scholars can benefit from examining the various structures that this construct is likely to comprise. This might provide a more precise insight into the bonding and damaging impact that the psychological contract is likely to engender because whilst expectations and obligations are 
characteristic of the business-to-business relationship (Dwyer, Schurr and Oh 1987) these have not been empirically decomposed into transactional and relational elements.

On this point, current literature suggests that whilst perceived inequity resulting from breaches to tangible terms (Guzzo and Noonan 1994) is relatively easy to rectify whereas failures in relation to the more nebulous elements of the contract are seemingly more difficult to remedy. However, the specific effects upon the overall relationship from breaches to each of these terms is also unclear in the employee relations literature because whilst there is much studies devoted to exploring the processes of forming, keeping and breaking the psychological contract, relatively little has been assigned to the content of the construct (Herriot, Manning and Kidd 1997). Perhaps marketing scholars need to examine the precise structures of these but this is likely to be further complicated by the multi-faceted nature of business-to-business relationships. These often involve the interaction of many boundary-spanning personnel from both firms at different levels of decision-making within each of these firms. Even the interaction between employees within the same firm will result in the formation of the psychological contract (Llewellyn 2001) and this could moderate the effectiveness of managing these relationships. The literature related to employee bonds show these to form through interaction with their employers through its agents, supervisors, peers, and, management (Anderson and Schalk 1998), suggesting the avenue that is designed to investigate these multiple interactions is likely to be most fruitful.

Finally, one of the key challenges in structuring the firm-customer relationship is selecting appropriate governance mechanisms (cf. Brown, Dev and Lee 2000; Cannon, Achrol and Gundlach 2000) that balance benefits gained from exchange with the need to safeguard relational inputs. In the broadest governance denotes a contracting problem (Gundlach and Achrol 1993) and in this respect social exchange has attempted to model the capability of relational norms to serve as apt governance mechanisms (Berthon, Pitt, Ewing and Bakkeland 2003; Cannon, Achrol and Gundlach 2000; Heide and John 1992; Joshi and Arnold 1998; Kaufmann and Stern 1988). Rousseau (1995) makes the clear distinction between relational norms and psychological contracts but makes the point that norms are likely to come into existence when the psychological contracts of parties overlap. The findings of this study show that relational behavior between parties result in the development of the psychological contract, however such a socialization process is also attributable to the development of relational norms (Axelrod 1986; Dwyer, Schurr and Oh 1987; Scanzoni 1979). From this vantage point, the relational orientation of the firm could effectively prove to be counter-productive as far as impeding the capabilities of such norms to help manage the relationship due to the concurrent presence of the psychological contract.

These effects are still unclear but what we do know is that norms constitute shared expectations and values that help guide patterns of appropriate behavior (Heide and John 1992; Joshi and Arnold 1998; Moch and Seashore 1981; Morgan and Hunt 1994) and seemingly help either party attain joint relational outcomes. Although psychological contracts assist in developing positive bonds within a relationship (Anderson and Schalk 1998) and also constitute strong beliefs about what both parties are obliged to for being in the relationship (Rousseau 1995; Rousseau and Tijoriwali 1998) these are highly idiosyncratic and reside in the mind of the individual (Rousseau 1995). From this vantage point, it would seem likely that as norms develop through socialization the parallel development of the psychological contract will result and thus the interactive effects of theses two constructs upon one another, as well as their conjoint impact upon governance will need to be examined. It is hoped that such a line of inquiry will help us further understand how managerial decision makers are able to develop effective governance mechanisms.

The research suggestions offered by this study are by no means exhaustive but irrespective of the precise trajectories that future research will follow the literature pertaining to the psychological contract provides clear evidence of the significance of this construct within the 
social exchange based marketing relationship. In this respect, this study suggests further pursuit of this largely overlooked construct will contribute to redefining the manner how scholars are currently modeling the firm-customer relationship. Such studies are likely to offer those managerial decision makers building and nurturing the social exchange relationship an opportunity to better understand the significance of their decisions. It is felt that those managers acknowledging the presence and consequences of psychological contracts inherent within their firm-customer relationships are likely to benefit most and thus provides impetus for further elaboration in the concluding section of this article.

\section{Conclusions and Managerial Implications}

This study extends the conceptual groundings of the important relational marketing paradigm within business-to-business relationships from the perspective of social exchange theory. The main purpose of the study was to establish the presence of psychological contracts and determine their interactive effects upon trust and commitment in distributor-supplier relationships within the motorized vehicle industry. Conclusive evidence of this has been provided through these findings, and, in doing so a range of managerial implications within this context have been identified that have broader marketing consequences. By offering a new conceptual perspective in the manner in which marketing relationships are being conceived, managerial decision makers can benefit from our knowledge because it not only shows the positive impact of their relational efforts but also indicates the potential negative implications of this strategy.

Underlying this discussion is the recognition that one of the key the challenges facing managers is their ability to model effective relationships that can attract commitment at the same time as ensuring their relational inputs are protected (Brown, Dev and Lee 2000; Cannon, Achrol, and Gundlach 2000; Morgan and Hunt 1994). The results of the study show clear evidence of how managers that adopt a relational orientation are able to increase trust and commitment $\left(\gamma_{11}\right.$ and $\left.\gamma_{31}\right)$ and the interactive effects of these two constructs upon one another $\left(\beta_{31}\right)$. Whilst this latter finding confirms existing knowledge in this area this study also reveals that this approach to relational building will also result in the formation of the psychological contract $\left(\gamma_{21}\right)$. Managers should therefore be aware that whilst the psychological contract is often nebulous and idiosyncratic in nature it provides them an alternative mechanism to help to increase the level of psychological and social bonding within the relationship (cf. Berry 1995). In this respect, they can 'leverage' the terms of the construct to help increase the level of trust and commitment directed towards them and this is as a direct consequence of their relational orientation $\left(\beta_{12}\right.$ and $\left.\beta_{32}\right)$.

However, they should be very mindful that terms of the psychological contract represent perceptions of promises and these engender bonding through reliance within the relationships. This is critical to understand because the making and, more importantly, keeping of promises are essential ingredients for relational marketing success (Bitner 1995; Grönroos 1990). Failures to perform some of the perceived terms that underpin this important relational bonding construct are inevitable (Rousseau and Parks 1993) but they can take solace because current literature reveals that not all contract violations are terminal. Overall, the development of the psychological contract will help them strengthen their relational bonds with the customer and lead to better relational outcomes provided that they recognize the construct exists and needs to be factored into their decision-making. 


\section{Appendix A: Construct and item descriptions}

\section{Relational Orientation}

Signaling Behavior (SIG1-3)

In our relationship, our major supplier...

SIG1. would try to cover up if they had a manufacturing setback.

SIG2. tends to be secretive about the politics in their company.

SIG3. tends to sidestep any talk about the weaknesses in their company.

(0-10 point strongly disagree... strongly agree scale; $*$ reverse scored)

\section{Disclosing Behavior (DIS1-5)}

In our relationship, our major supplier...

DIS1. gives us ample notice of any planned price changes.

DIS2. does a good job in notifying advance delivery schedules.

DIS3. informs us of any changes in billing procedures well ahead of time.

DIS4. informs us early of any plans to change their products.

DIS5. gives us plenty of notice if their level of after-sales service was to change.

(0-10 point strongly disagree... strongly agree scale; $*$ reverse scored)

\section{Initiating Behavior (INI1-6)}

In our relationship, our major supplier...

INI1. spends time learning how to help us lower costs in distributing our products.

INI2. spends time trying to help us gain maximum benefit from their products.

INI3. makes effort to keep themselves abreast of our customer's changing needs.

INI4. shows an active interest in helping us become more competitive.

INI5. keeps themselves abreast with changes in our competitive environment.

INI6. shows an active interest in trying to understand how our firm works.

(0-10 point strongly disagree... strongly agree scale)

\section{Trust (TR1-7)}

In our relationship, our major supplier...

T1. cannot be trusted at times*.

T2. is perfectly honest and truthful.

T3. can be trusted completely.

T4. can be counted on to do what is right.

T5. is always faithful.

T6. is someone that I have great confidence in.

T7. has high integrity.

(0-10 point strongly disagree... strongly agree scale; $*$ reverse scored)

\section{Commitment (CT1-6)}

The relationship that my firm has with our major supplier...

C1. is something that we are very committed to.

C2. is very important to my firm.

C3. is of little significance to us. *

C4. is something my firm intends to maintain definitely.

C5. is very much like being family.

C6. is something my firm really cares about.

C7. deserves our firm's maximum attention to maintain.

(0-10 point strongly disagree... strongly agree scale; * reverse scored) 


\section{Psychological Contracts}

1. Good Faith \& Fair Dealing (GFFD1-6)

In the relationship with our major supplier, they have promised...

GFFD1. a collaborative work environment between our firms.

GFFD2. candid and open feedback within our relationship.

GFFD3. respect for our firm's efforts within the relationship.

GFFD4. a cooperative working relationship between our firms.

GFFD5. honest treatment towards our firm in the relationship.

GFFD6. professional and collegiality directed towards our firm.

(0-10 point scale... strongly disagree... strongly agree)

\section{Relational Benefits (RB1-6)}

In the relationship with our major supplier, they have promised...

RB1. attractive benefits package to your firm to distribute their products.

RB2. positive financial returns tied to your firms performance.

RB3. a flexible benefits package for distributing their products.

RB4. good opportunities for advancing your firm.

RB5. extra bonuses linked to your firm's performance.

(0-10 point scale... strongly disagree... strongly agree)

\section{Relational Conditions (RC1-6)}

In the relationship with our major supplier, they have promised...

RC1. the tools necessary for your firm to perform its role effectively.

RC2. an environment that promotes the opportunity for your firm to learn.

RC3. materials and equipment needed by your firm to perform its role.

RC4. a clean and safe work environment for your firm to operate in.

RC5. necessary skill development for your firm's employees.

RC6. further training and/or information for employees within your firm.

(0-10 point scale... strongly disagree... strongly agree)

\section{Intrinsic Relational Characteristics (IRC1-5)}

In the relationship with our major supplier, they have promised...

IRC1. a relationship role that is interesting to your firm.

IRC2. a meaningful role for your firm within the relationship.

IRC3. a distribution role that provides your firm with high levels of autonomy.

IRC4. a distribution role that is challenging to your firm.

IRC5. a distribution role that has high levels of responsibility.

(0-10 point scale... strongly disagree... strongly agree) 
Appendix B: Factor Structure for Psychological Contract

\begin{tabular}{|c|c|c|c|c|}
\hline Items & GFFD & Conditions & Benefits & Characteristics \\
\hline GFFD1 & 0.730 & & & \\
\hline GFFD2 & 0.830 & & & \\
\hline GFFD3 & 0.859 & & & \\
\hline GFFD4 & 0.901 & & & \\
\hline GFFD5 & 0.885 & & & \\
\hline GFFD6 & $0.774(25.94)^{\mathrm{a}}$ & & & \\
\hline $\mathrm{RC} 1$ & & 0.663 & & \\
\hline $\mathrm{RC} 2$ & & 0.666 & & \\
\hline $\mathrm{RC} 3$ & & 0.731 & & \\
\hline $\mathrm{RC} 4$ & & 0.600 & & \\
\hline RC5 & & 0.788 & & \\
\hline RC6 & & $0.757(43.03)$ & & \\
\hline RB1 & & & 0.739 & \\
\hline RB2 & & & 0.853 & \\
\hline RB3 & & & 0.817 & \\
\hline RB4 & & & 0.480 & \\
\hline RB5 & & & $0.835(59.41)$ & \\
\hline IRC1 & & & & 0.571 \\
\hline IRC2 & & & & 0.604 \\
\hline IRC3 & & & & 0.668 \\
\hline IRC4 & & & & 0.774 \\
\hline IRC5 & & & & $0.689(73.81)$ \\
\hline
\end{tabular}

${ }^{\mathrm{a}}$ Cumulative variance 
Appendix C: Principal Components Factor Analysis on all Construct Items

\begin{tabular}{|c|c|c|c|c|c|c|c|c|c|}
\hline \multirow{2}{*}{ Items } & \multicolumn{3}{|c|}{ Relational Orientation } & \multicolumn{4}{|c|}{ Psychological Contract } & \multirow{2}{*}{$\begin{array}{c}\text { Trust } \\
\text { TR } \\
\end{array}$} & \multirow{2}{*}{$\frac{\text { Commitment }}{\mathrm{CM}}$} \\
\hline & RIB & RDB & RSB & $\mathrm{RC}$ & GFFD & $\mathrm{RB}$ & IRC & & \\
\hline RIB1 & 0.600 & & & & & & & & \\
\hline RIB2 & 0.710 & & & & & & & & \\
\hline RIB3 & 0.748 & & & & & & & & \\
\hline RIB4 & 0.734 & & & & & & & & \\
\hline RIB5 & 0.748 & & & & & & & & \\
\hline RIB6 & 0.675 & $02)^{a}$ & & & & & & & \\
\hline RDB1 & & 0.741 & & & & & & & \\
\hline RDB2 & & 0.648 & & & & & & & \\
\hline RDB3 & & 0.787 & & & & & & & \\
\hline RDB4 & & 0.549 & & & & & & & \\
\hline RDB5 & & $0.570(1$. & & & & & & & \\
\hline RSB1 & & & 0.760 & & & & & & \\
\hline RSB2 & & & 0.857 & & & & & & \\
\hline RSB3 & & & $0.854(20.11)$ & & & & & & \\
\hline $\mathrm{RC} 1$ & & & & 0.643 & & & & & \\
\hline $\mathrm{RC} 2$ & & & & 0.618 & & & & & \\
\hline $\mathrm{RC} 3$ & & & & 0.703 & & & & & \\
\hline $\mathrm{RC} 4$ & & & & 0.577 & & & & & \\
\hline RC5 & & & & 0.763 & & & & & \\
\hline RC6 & & & & $0.725(27.24)^{\mathrm{a}}$ & & & & & \\
\hline GFFD1 & & & & & 0.660 & & & & \\
\hline GFFD2 & & & & & 0.760 & & & & \\
\hline GFFD3 & & & & & 0.793 & & & & \\
\hline GFFD4 & & & & & 0.827 & & & & \\
\hline GFFD5 & & & & & 0.782 & & & & \\
\hline GFFD6 & & & & & $0.698(38.25)^{\mathrm{a}}$ & & & & \\
\hline RB1 & & & & & & 0.717 & & & \\
\hline RB2 & & & & & & 0.839 & & & \\
\hline RB3 & & & & & & 0.800 & & & \\
\hline RB4 & & & & & & 0.772 & & & \\
\hline RB5 & & & & & & $0.800(45.80)^{\mathrm{a}}$ & & & \\
\hline IRC1 & & & & & & & 0.512 & & \\
\hline IRC2 & & & & & & & 0.562 & & \\
\hline IRC3 & & & & & & & 0.643 & & \\
\hline IRC4 & & & & & & & 0.721 & & \\
\hline IRC5 & & & & & & & $0.637(51$ & $79)^{\mathrm{a}}$ & \\
\hline TR1 & & & & & & & & 0.704 & \\
\hline TR2 & & & & & & & & 0.680 & \\
\hline TR3 & & & & & & & & 0.741 & \\
\hline TR4 & & & & & & & & 0.775 & \\
\hline TR5 & & & & & & & & 0.762 & \\
\hline TR6 & & & & & & & & 0.765 & \\
\hline TR7 & & & & & & & & $0.792(65.26)^{\mathrm{a}}$ & \\
\hline CM1 & & & & & & & & & 0.776 \\
\hline CM2 & & & & & & & & & 0.758 \\
\hline CM3 & & & & & & & & & 0.610 \\
\hline CM4 & & & & & & & & & 0.586 \\
\hline CM5 & & & & & & & & & 0.616 \\
\hline CM6 & & & & & & & & & 0.640 \\
\hline CM7 & & & & & & & & & $0.815(72.53)^{\mathrm{a}}$ \\
\hline
\end{tabular}

${ }^{\mathrm{a} C}$ Cumulative variance 


\section{References}

Anderson, Erin and Barton Weitz (1992), "The Use of Pledges to Build and Sustain Commitment in Distribution Channels", Journal of Marketing Research, XXIX, (February), 18-34.

Anderson, James C. and David W. Gerbing (1988), "Structural Equation Modeling in Practice: A Review and Recommended Two-Step Approach", Psychological Bulletin, 103, 411-423.

Anderson, James C. and James A. Narus (1984), "A Model of the Distributor's Perspective of Distributor-Manufacturer Working Partnerships”, Journal of Marketing, 48, 62-74.

Anderson, James C. and James A. Narus (1990), "A Model of Distributor Firm and Manufacturer Firm Working Partnerships", Journal of Marketing, 54, 42-58.

Anderson, Neil and René Schalk (1998), "The Psychological Contract in Retrospect and Prospect", Journal of Organizational Behaviour, 19, 637-647.

Armstrong, Scott J. and Terry S. Overton (1977), "Estimating Non-Response Bias in Mail Surveys", Journal of Marketing Research, Volume XIV, (August), 396-402.

Axelrod, Robert (1986), “An Evolutionary Approach to Norms”, American Political Science Review, 80, (December), 1095-1111.

Berry, Leonard L. (1995), "Relationship Marketing of Services: Growing Interest, Emerging Perspectives", Journal of the Academy of Marketing Sciences, 23, 236-245.

Berthon, Pierre, Leyland F., Pitt, Michael T., Ewing and Gunnar Bakkeland (2003), "Norms and Power in Marketing Relationships: Alternative Theories and Empirical Evidence", Journal of Business Research, 56, 699-709.

Bitner, Mary J. (1995), "Building Services Relationships: Its all about Promises", Journal of the Academy of Marketing Sciences, 23, 246-251.

Blau, Peter M. (1964), Exchange and Power in Social Life, New York: John Wiley and Sons.

Boyle, Brett F., Robert Dwyer, Robert A. Robicheaux, and James T. Simpson (1992), "Influence Strategies in Marketing Channels: Measures and Use in Different Relationship Structures", Journal of Marketing Research, XXIX, (November), 462-473.

Brown, James R., Chekitan S. Dev and Dong-Jin Lee (2000), "Managing Marketing Channel Opportunism: The Efficacy of Alternative Governance Mechanisms", Journal of Marketing, 64, (April), 51-65.

Cannon, Joseph P., Ravi S. Achrol and Gregory T. Gundlach (2000), "Contracts, Norms and Plural Form Governance", Academy of Marketing Science, 28, 180-194.

Carman, James M. (1980), "Paradigms for Marketing Theory", (1-36), In, Research in Marketing, Volume 3, Jagdish N. Sheth (Ed.), Greenwich, CT: JIA Press.

Crosby, Lawrence A., Kenneth R. Evans, and Deborah Cowles (1990), "Relationship Quality in Services Selling: An Interpersonal Influence Perspective", Journal of Marketing, 54, 68-81.

De-Meuse, Kenneth P., Thomas J. Bergmann and Scott W. Lester (2000), "An Investigation of the Relational Component of the Psychological Contract Across Time, Generation and Employment Status", Journal of Managerial Issues, 13, (Spring), 102-118.

Deutch, Morton (1962), "Trust and Suspicion", Journal of Conflict Resolution, 11, (December), 265-279.

Dillman, Don A. (1991), "The Design and Administration of Mail Surveys", Annual Review of Psychology, 17, 225-249.

Dillman, Don A. (2000), Mail and Internet Surveys: The Tailored Design Method, Second Edition, New York: John Wiley.

Dion, Paul A., Peter M. Banting and Loretta M. Hasey (1990), "The Impact of JIT on Industrial Marketers", Industrial Marketing Management, 19, (February), 41-46.

Doney, Patricia. M. and Joseph P. Cannon (1997), "An Examination of the Nature of Trust in BuyerSeller Relationships”, Journal of Marketing, 61, (April), 35-51.

Duncan, Tom and Sandra E. Moriarty (1998), "A Communication Based Model for Managing Relationships", Journal of Marketing, 62, (April), 1-13.

Dwyer, Robert F., Paul H. Schurr, and Sejo Oh (1987), "Developing Buyer-Seller Relationships", Journal of Marketing, 51, (April), 11-27.

Ekeh, Peter P. (1974), Social Exchange Theory: The Two Traditions, London: Heinemann.

Farrell, Dan (1983), "Exit, Voice, Loyalty and Neglect as Responses to Job Dissatisfaction: A Multidimensional Scaling Study", Academy of Management Journal, 26, (December), 596-607. 
Ford, David I. (1978), "Stability Factors in Industrial Marketing Channels", Industrial Marketing Management, 7, 410-422.

Ford, David I. (1980), "The Development of Buyer-Seller Relationships in Industrial Markets," European Journal of Marketing, 14, 339-353.

Ganesan, Shankar (1994), "Determinants of Long-Term Orientation in Buyer-Supplier Relationships", Journal of Marketing, 58, (April), 1-19.

Garbarino, Ellen and Mark S. Johnson (1999), "The Different Roles of Satisfaction, Trust, and Commitment in Customer Relationships", Journal of Marketing, 63, (April), 70-87.

Gordon, Mary E., Kim McKeage and Mark A. Fox (1998), "Relationship Marketing Effectiveness: The Role of Involvement", Psychology and Marketing, 15, 443-459.

Gouldner, Alvin W. (1960), "The Norm of Reciprocity: A Preliminary Statement", American Sociological Review, 25, 161-178.

Grönroos, Christian (1990), "Relationship Approach to Marketing in Services Contexts: The Marketing and Organizational Behavior Interface", Journal of Business Research, 20, 3-11.

Guest, David E. (1998), "Is the Psychological Contract Worth Taking Seriously?" Journal of Organizational Behaviour, 19, 649-664.

Gundlach, Gregory T. and Ravi S. Achrol (1993), "Governance in Exchange: Contract Law and its Alternatives", Journal of Public Policy and Marketing, 12, (Fall), 141-155.

Gundlach, Gregory T, Ravi S. Achrol, and John T. Mentzer (1995), "The Structure of Commitment in Exchange", Journal of Marketing, 59, (January), 78-92.

Guzzo, Richard A. and Katherine A. Noonan (1994), "Human Resources Practices as Communications and the Psychological Contract", Human Resources Management, 33, 447-462.

Håkansson, Håkan (1982), International Marketing and Purchasing Management of Industrial Goods: An Interactive Approach, New York: John Wiley and Sons.

Hallén, Lars, Jan Johanson, and Nazeem Seyed-Mohamed (1991), "Inter-Firm Adaptations in Business Relationships", Journal of Marketing, 55, (April), 29-37.

Heide, Jan B. and George John (1990), "Alliances in Industrial Purchasing: The Determinants of Joint Action in Buyer-Supplier Relationships", Journal of Marketing Research, XXVII, (February), 24-36.

Heide, Jan B. and George John (1992), "Do Norms Matter in Marketing Relationships?" Journal of Marketing, 56, (April), 32-44.

Heide, Jan B. and Anne S. Milner (1992), "The Shadow of the Future: Effects of Anticipated interaction and Frequency of Contact on Buyer-Seller Cooperation", Academy of Management Journal, 35, 265291.

Herriot, Peter, W. E. G. Manning, and Jennifer M. Kidd (1997), "The Content of Psychological Contract", British Journal of Management, 8, 151-162.

Hirschman, Albert O. (1970), Exit, Voice and Loyalty: Responses to Decline in Firms, Organizations and States, Cambridge, MA: Harvard University Press.

Homans, George C. (1961), Social Behaviour: Its Elementary Forms, New York: Harcourt.

Huston, Ted L. and Robert L. Burgess (1979), "The Analysis of Social Exchange in Developing Relationships", (3-28), In, Burgess, Robert L. and Ted L. Huston (Eds.) Social Exchange in Developing Relations, New York: Academic Press.

Jones, Gareth R. and Jennifer M. George (1998), "The Experience and Evolution of Trust: Implications for Cooperation and Teamwork" Academy of Management Review, 23, 531-546.

Joshi, Ashwin W. and Stephen J. Arnold (1997), "The Impact of Buyer Dependence on Buyer Opportunism in Buyer-Supplier Relationships: The Moderating Role of Relational Norms", Psychology and Marketing, 14, 823-845.

Kanuk, Leslie and Conrad Berenson (1975), "Mail Surveys and Response Rates: A Literature Review" Journal of Marketing Research, 12, (November), 400-453.

Kaufmann, Patrick J. and Louis W. Stern (1988), "Relational Exchange Norms, Perceptions of Unfairness, and Retained Hostility in Commercial Litigation", Journal of Conflict Resolution, 33, (September), 534-552.

Kickul, Jill (2001), "Promises Made, Promises Broken: An Exploration of Employee Attraction and Retention Practices in Small Business", Journal of Small Business Management, 39, 320-335.

Kingshott, Russel P. J. (2002), "Psychological Contracts Within Supplier-Distributor Relationships" IMP Conference, Perth, Western Australia, 11-13 December. 
Leuthesser, Lance (1997), "Supplier Relational Behaviour: An Empirical Assessment", Industrial Marketing Management, 26, 245-254.

Leuthesser, Lance and Ajay K. Kohli (1995), "Relational Behavior in Business Markets: Implications for Marketing Management", Journal of Business Research, 34, 221-233.

Llewellyn, Nick (2001), "The Role of Psychological Contracts within Internal Service Encounters", The Service Industries Journal, 21, (January), 211-226.

Moch, Michael and Stanley E. Seashore (1981), "How Norms Affect Behaviours in Corporations", (211237), In, Nystrom, Paul C. and William H. Starbuck (Eds.) Handbook of Organizational Design: Adapting Organizations to Their Environments, 1, Oxford University Press.

Moorman, Christine, Gerald Zaltman and Rohit Deshpandé (1992), "Relationships Between Providers and Users of Market Research: The Dynamics of Trust Within and Between Organizations", Journal of Marketing Research, XXIV, (August), 314-328.

Morgan, Robert M. and Shelby D. Hunt (1994), "The Commitment Trust Theory of Relationship Marketing", Journal of Marketing, 58, (July), 20-38.

Morrison, Elizabeth W. and Sandra L. Robinson (1997), "When Employees Feel Betrayed: A Model of How Psychological Contract Violation Develops", Academy of Management Review, 22, (January), 226-256.

Noordewier, Thomas G., George John, and John R. Nevin, (1990), "Performance Outcomes of Purchasing Arrangements in Industrial Buyer Vendor Relationships", Journal of Marketing, (October), 80-93.

Rexha, Nexhi, Russel P. J. Kingshott and Audrey Aw (2003). "The Impact of the Relational Plan on Adoption of Electronic Banking", Journal of Services Marketing, 17, 53-65.

Rindfleisch, Aric and Jan B. Heide (1997), "Transactional Cost Analysis: Past, Present and Future Applications", Journal of Marketing, 61, (October), 30-54.

Robinson, Sandra L. (1996), "Trust and Breach of the Psychological Contract", Administrative Science Quarterly, 41, 574-599.

Robinson, Sandra L., Kraatz and Denise M. Rousseau (1994), "Changing Obligations and the Psychological Contract: A Longitudinal Study", Academy of Management Journal, 37, 137-152.

Robinson, Sandra L. and Denise M. Rousseau (1994), "Violating the Psychological Contract: Not the Exception but the Norm", Journal of Organizational Behaviour, 15, 245-259.

Rousseau, Denise M. (1989), "Psychological and Implied Contracts in Organizations", Employee Rights and Responsibilities Journal, 2, 121-139.

Rousseau, Denise M. (1990), "New Hire Perceptions of their own and their Employer's Obligations: A Study of Psychological Contracts", Journal of Organizational Behaviour, 11, 389-400.

Rousseau, Denise M. (1995), Psychological Contracts in Organizations: Understanding Written and Unwritten Agreements, Newbury Park, CA: Sage Publications.

Rousseau, Denise M. (1996)(C), Psychological Contract Measures, Carnegie Mellon University, Pittsburgh, PA.

Rousseau, Denise M. and Judy M. Parks (1993), "The Contracts of Individuals and Organizations", (143), In, Cummings L. L. and B. M. Staw (Eds.) Research in Organizational Behaviour, 15, Connecticut: JAI Press.

Rousseau, Denise M. and Snehal A. Tijoriwala (1998), “Assessing Psychological Contracts: Issues, Alternatives and Measures", Journal of Organizational Behaviour, 19, 679-695.

Rusbult, Caryl E., Dan Farrell, Glen Rogers, and Arch G. Mainous III (1988), "Impact of Exchange Variables on Exit, Voice, Loyalty, and Neglect: An Integrative Model of Responses to Declining Job Satisfaction", Academy of Management Review, 31, (September), 599-627.

Scanzoni, John (1979), "Social Exchange Behavioural Interdependence”, (61-98), In, Burgess, Robert L. and Ted Huston (Eds.) Social Exchange in Developing Relationships, New York: Academic Press.

Schuns, Jos M. C. and Gaby J. Schröeder (1996), "Segmentation Selection by Relationship Strength", Journal of Direct Marketing, 10, (Summer), 69-79.

Sheth, Jagdesh N. and Atul Parvatiyar (1995), "The Evolution of Relationship Marketing", International Business Review, 4, 397-418.

Smith, Brock J. and Donald W. Barclay (1997), "The Effects of Organizational Differences and Trust on the Effectiveness of Selling Partner Relations", Journal of Marketing, 61, (January), 3-21.

Swan, John E. and James K. Nolan (1985), "Gaining Customer Trust: A Conceptual Guide for the Salesperson”, Journal of Personal Selling and Sales Management, 5, (November), 39-48. 
Thibaut, John W. and Harold H. Kelly (1959), The Social Psychology of Groups, New York: John Wiley and Sons, Inc.

Turnley, William H. and Daniel C. Feldman (1998), "Psychological Contract Violations During Corporate Restructuring", Human Resource Management, 37, (Spring), 71-83.

Turnley, William H. and Daniel C. Feldman (1999), "The Impact of Psychological Contract Violations on Exit, Voice, Loyalty and Neglect", Human Relations, Volume 52, (July), 895-917.

Webster, Fredrick E. (1992), "The Changing Role of Marketing in the Corporation", Journal of Marketing, 56, (October), 1-17.

Weitz, Barton A. and Sandy D. Jap (1995), "Relationship Marketing and Distribution Channels", Journal of the Academy of Marketing Science, 23, 305-320.

Wiener, Joshua L. and Tabitha A. Doescher (1994), "Cooperation and Expectations of Cooperation", Journal of Public Policy and Marketing, 13, 259-270.

Williams, Michele (2001), "In Whom We Trust: Group Membership as an Effective Context for Trust Development" Academy of Management Review, 26, 377-396.

Williamson, Oliver E. (1975), Markets and Hierarchies, London: The Free Press.

Williamson, Oliver E. (1979), "Transaction Cost Economics: The Governance of Contractual Relations", Journal of Law and Economics, 22, (October), 233-261.

Williamson, Oliver E. (1983), "Credible Commitments: Using Hostages to Support Exchange", The American Economic Review, 73, (September), 519-540.

Wilson, David T. (1990), "Creating and Managing Buyer-Seller Relationships", Institute for the Study of Business Markets, Pennsylvania State University: Working Paper Series, ISBM Report 5.

Wilson, David T. (1995), "An Integrated Model of Buyer-Seller Relationships", Journal of the Academy of Marketing Science, 23, 335-245. 